\title{
Microstructural Analysis of Co-Free Maraging Steel Aged
}

\author{
Aline Castilho Rodrigues ${ }^{1}$, Heide Heloise Bernardi ${ }^{1}$, Jorge Otubo²
}

\begin{abstract}
Maraging steels have low carbon content and are highly alloyed, having as main feature the ability to increase the mechanical strength after thermal aging. Therefore, the objective of this work is to analyze the effect of aging in a Cofree maraging steel, $\mathrm{Fe}-0.014 \% \mathrm{C}-0.3 \% \mathrm{Mn}-3.9 \% \mathrm{Mo}-$ 2. $1 \% \mathrm{Cu}-0.19 \% \mathrm{Si}-11.8 \% \mathrm{Cr}-9.1 \% \mathrm{Ni}-1.0 \% \mathrm{Ti}(\mathrm{wt})$, at different heat treatment times (10 min - $960 \mathrm{~min}$ ) at constant temperature $\left(550^{\circ} \mathrm{C}\right.$ ), after cold rolling up to $66 \%$ and $77 \%$ area reduction. Microstructures were analyzed by scanning electron microscopy (SEM - EDS) and mechanical properties by Vickers hardness measurements. The results showed a significant increase in the hardness of the material after aging heat treatment on the solution treated and deformed samples. The aging heat treatment which was harder about $650 \mathrm{HV}$ was $550^{\circ} \mathrm{C} / 60 \mathrm{~min}$.
\end{abstract}

KEYWORDS: Maraging steel, Cold rolling, Hardness test Aging.

\section{INTRODUCTION}

Maraging steel was developed in the 1950's, to support the demand for a low density and temperature resistant steel $\left(250^{\circ} \mathrm{C}-300^{\circ} \mathrm{C}\right)$, for improving aircraft performance. This new material was created adding aluminum $(\mathrm{Al})$ and titanium $(\mathrm{Ti})$ in steel with nickel (Ni). In the 1960's, cobalt (Co) and molybdenum (Mo) were added into the composition of maraging steels. Clarence George Bieber, in International Nickey Company, studied the addition of these elements in the alloy and concluded that there is a significant increasing in mechanical resistance (Lopes, 2007; Méndez, 2000). The classification of commercial maraging steels, according to the percentage of nickel, is: $18 \mathrm{Ni}$ (250), 18Ni (300) and 18Ni (350) (Lopes, 2007).

Maraging steel received this name due to two words: martensite and aging, which mean martensite aged. Low carbon and alloyed, the maraging steels are capable of increasing their mechanical resistance and hardness after aging heat treatments. The treated solution state has a martensitic structure with high ductility and toughness, and it can be modified after aging heat treatments (Cardoso et al., 2013a). Due to the ductility of martensite, the maraging steel allows cold mechanical forming, not requiring intermediate heat treatment. A mechanical processing technique that can be used in maraging steel is cold rolling.

During the cold rolling, plastic deformation and increase of hardness occur, therefore, there is an increasing of dislocation density and crystalline defects, hindering the movement between them. Due to the plastic deformation, there is an increase in tensile strength and yield point (Callister, 2012). On the other hand, these mechanical properties can also be improved by thermal aging, in which the formation of intermetallic precipitates occurs. In Table 1,the types of precipitates which may be formed 
Table 1. Precipitates hardeners formed during the aging of maraging steels (Padial et al., 2000).

\begin{tabular}{|c|c|}
\hline Phase & Crystalline Structure \\
\hline $\mathrm{Ni}_{3} \mathrm{Mo}$ & Orthorhombic \\
\hline $\mathrm{Ni}_{3} \mathrm{Ti}$ & Hexagonal ordered \\
\hline $\mathrm{Ni}_{3} \mathrm{~V}$ & Hexagonal compact \\
\hline $\mathrm{Ni}_{3} \mathrm{~W}$ & Orthorhombic \\
\hline $\mathrm{Fe}_{2}(\mathrm{Mo}, \mathrm{Ti})$ & Type hexagonal laves \\
\hline $\mathrm{FeMo}$ & Tetragonal \\
\hline $\mathrm{FeTi}$ & CsCl type cubic \\
\hline $\mathrm{Fe}$ & $\mathrm{Mo}$ \\
4 & Hexagonal \\
\hline $\mathrm{R}(\mathrm{Mo}-\mathrm{Co}-\mathrm{Cr})$ & Hexagonal rhombic \\
\hline $\mathrm{X}(\mathrm{Fe}-\mathrm{Cr}-\mathrm{Mo})$ & Body-centered cubic \\
\hline
\end{tabular}

on maraging steels, depending on the alloy composition, are shown (Padial et al., 2000).

Steel with martensitic structure, when subjected to a heat treatment at a constant temperature, suffers a growth of intermetallic precipitates uniformly in the matrix (Carvalho et al., 2013). The precipitate size is a contributing factor to the increased mechanical resistance of maraging steels. The smaller the precipitates and the more coherent with the matrix, the greater the hardness of the alloy, since there is less space between the particles; furthermore, they act as barriers to movement of dislocations (Padial et al., 2000).

The alloying elements of maraging steel, such as molybdenum, titanium, nickel, cobalt, aluminum, and others, have a great influence on the mechanical properties of this alloy, in other words, they are responsible by precipitates hardeners (Carvalho et al., 2013). However, recent studies (Hu et al., 2008; Leitner et al., 2011; Mahmoudi et al., 2011; Mahmudi et al., 2011; Nili-Ahmadabadi, 2008; Schnitzer et al., 2010; Sha et al., 2013) are being conducted in maraging steels without cobalt addition, in order to reduce the production costs of this alloy. Maraging steels are considered expensive due to their materials' preparation and expensive alloy elements such as nickel and cobalt processes. The elimination of the cobalt content and the substitution of nickel by cheaper elements, such as manganese, has been studied. Cobalt is used only to minimize the solubility of molybdenum. In the case of maraging steel studied, this element was replaced by chrome, which besides improving the hardenability increases the corrosion resistance (Nili-Ahmadabadi, 2008).

Maraging steels are mainly applied in the aeronautical, aerospace, nuclear and military industries, as they have great advantages such as good weldability, high strength, high yield strength, high fracture toughness, they support high working temperatures, have good machinability, good formability, among others, with great applicability matrices and tools (Lopes, 2007).

High-tensile steels such as $300 \mathrm{M}$ and SAE 4340 have extensive application in aeronautics and aerospace industry, being mainly applied in the manufacture of structural components (Zang et al., 2013; Boakye-Yiadom et al., 2014).

Maraging steels are being investigated because of the possibility of replacing the commercial alloy steels, $300 \mathrm{M}$ and 4340 for example, widely used in aeronautical industry (Carvalho et al., 2013). Thus, this study aims to examine the effect of aging heat treatment in non-commercial maraging steel (Co-free), in order to compare it to the $300 \mathrm{M}$ and 4340 steels.

\section{EXPERIMENTAL}

The maraging steel used in this work was produced by vacuum induction melting. The ingots was hot forged and then hot rolled until we obtained bars of 20x20 mm of dimension and chemical composition: $\mathrm{Fe}-0.014 \% \mathrm{C}-0.3 \% \mathrm{Mn}-3.9 \%$ $\mathrm{Mo}-2.1 \% \mathrm{Cu}-0.19 \% \mathrm{Si}-11.8 \% \mathrm{Cr}-9.1 \% \mathrm{Ni}-1.0 \% \mathrm{Ti}$ (wt.\%).

Its bar $(20 \times 20 \mathrm{~mm})$ was separated into two parts resulting in two conditions:

- Condition I (C-I): bar dimension of 20 x 20 x 10 mm;

- Condition II (C-II): bars of 20 x 20 x 10 mm ( 100 wt.), remelted (1 remelt) on an arc furnace, resulting in an ingot dimension of 16x10x95 mm.

Both conditions (C-I and C-II) were solution treated at $1050^{\circ} \mathrm{C}$ during 1 hour, quenched in water at room temperature and then cold rolled to a plate of $3 \mathrm{~mm}$ in thickness, resulting in 66 and $77 \%$ of area reduction (AR) for C-I and C-II, respectively. The deformed samples ( $\mathrm{AR}=66$ and $77 \%$ ) were cut in several parts and each part was annealed at $550^{\circ} \mathrm{C}$ for different times, ranging from 10 to $960 \mathrm{~min}$.

Microstructural characterization was performed using a Scanning Electron Microscope (SEM) VEGA 3 TESCAN model, equipped with an energy dispersive spectrometer system (EDS). Vickers hardness 
testing was performed using a Future-Tech FM-7000 microindenter with a load of $200 \mathrm{~g} / 15 \mathrm{~s}$, in which the results correspond to the mean of ten values taken on each specimen. The micrograph analyses and the Vickers' hardness were undertaken in a longitudinal section of the samples (wire rolling direction).

\section{RESULTS AND DISCUSSION}

Figure 1 shows the hardness variation as a function of heat treatment time for maraging steel with AR's $=66$ and $77 \%$. For solution treated (C-I and C-II) and deformed samples, the hardness values are represented at zero time in Fig. 1.

Solution treated samples (C-I and C-II) showed average hardness values of 250 and $300 \mathrm{HV}$, respectively. Comparing the solution treated to the deformed condition, it is observed an increase around $50 \%$ in average hardness values $\left(\mathrm{HV}_{66 \%}=425\right.$ and $\mathrm{HV}_{77 \%}=407$ ), corresponding to the effect of work hardening. About thermal aging, there is a significant increase in hardness at relatively low heat treating times (Fig. 1). For both area reductions, increased hardness around $200 \mathrm{HV}$ occurs with only $10 \mathrm{~min}$ thermal aging. He et al. (2002) observed that the heat treatment at $470^{\circ} \mathrm{C}$ performed in a maraging steel with $18 \% \mathrm{wt}$. $\mathrm{Ni}$, after forging, has achieved a $90 \%$ increase in hardness, with only 15 min of aging.

In the detail of Fig. 1, it is observed that the maximum hardness is obtained at $550^{\circ} \mathrm{C} / 60 \mathrm{~min}$ for both ARs. On the other hand, the thermal aging at $550^{\circ} \mathrm{C}$ exhibits a decrease in hardness values after $240 \mathrm{~min}$ for deformed sample with $\mathrm{AR}=66 \%$, whereas a decrease it is observed after 90 min to condition $\mathrm{AR}=77 \%$. Therefore, it can be said that in smaller ARs, there is an increase in aging time of the alloy, delaying the onset of overaging. Based on the average hardness values, the processing) in the matrix, resulting in a lath martensitic structure (Mahmoudi et al., 2011; Hu and Wang, 2012), as shown in Figs. 2a and 2b. Co-free maraging steel is stable up to 16 hours of aging at $550^{\circ} \mathrm{C}$.

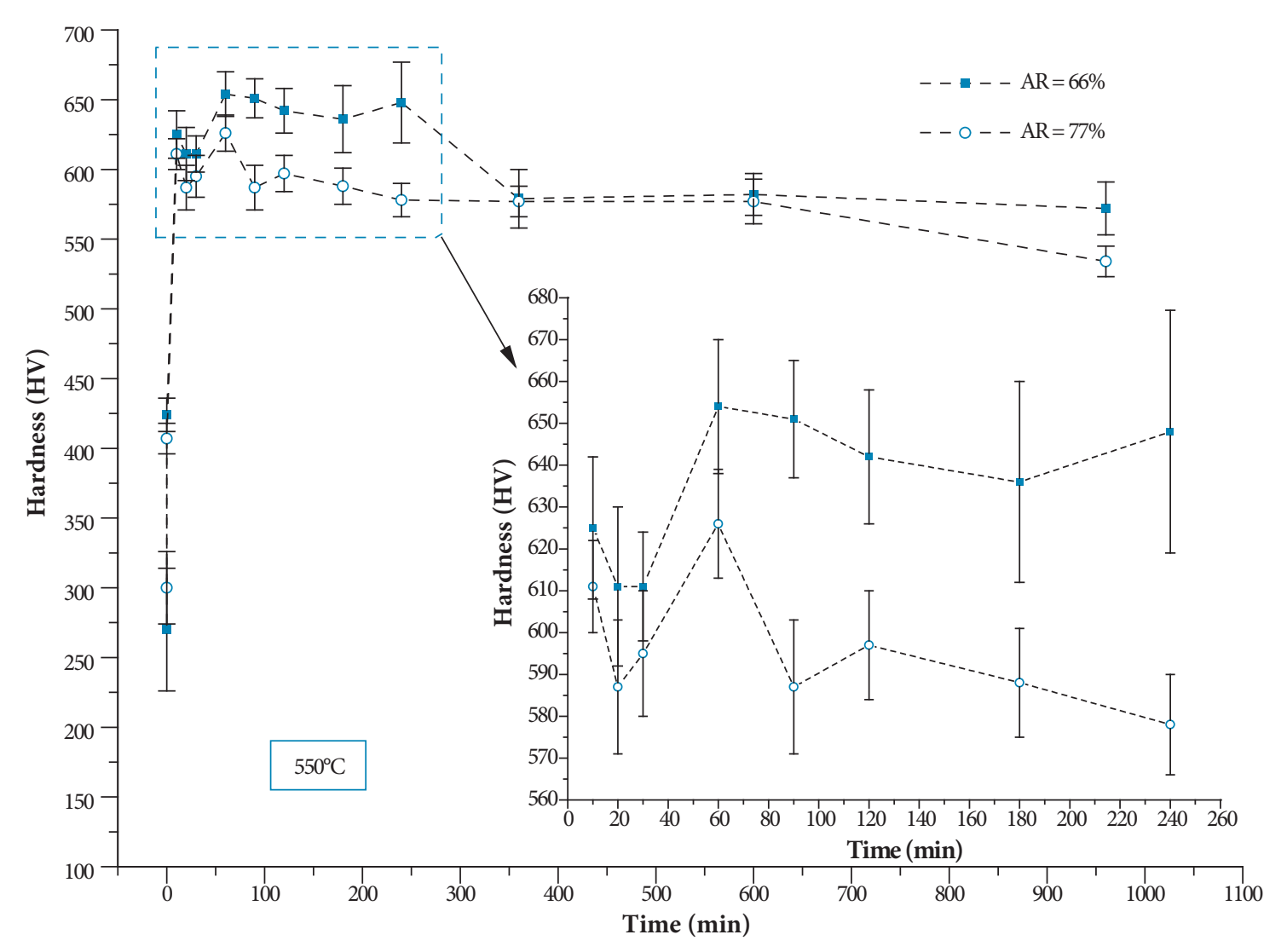

Figure 1. Annealing behavior of the maraging steel deformed with AR's $=66 \%$ and $77 \%$. 


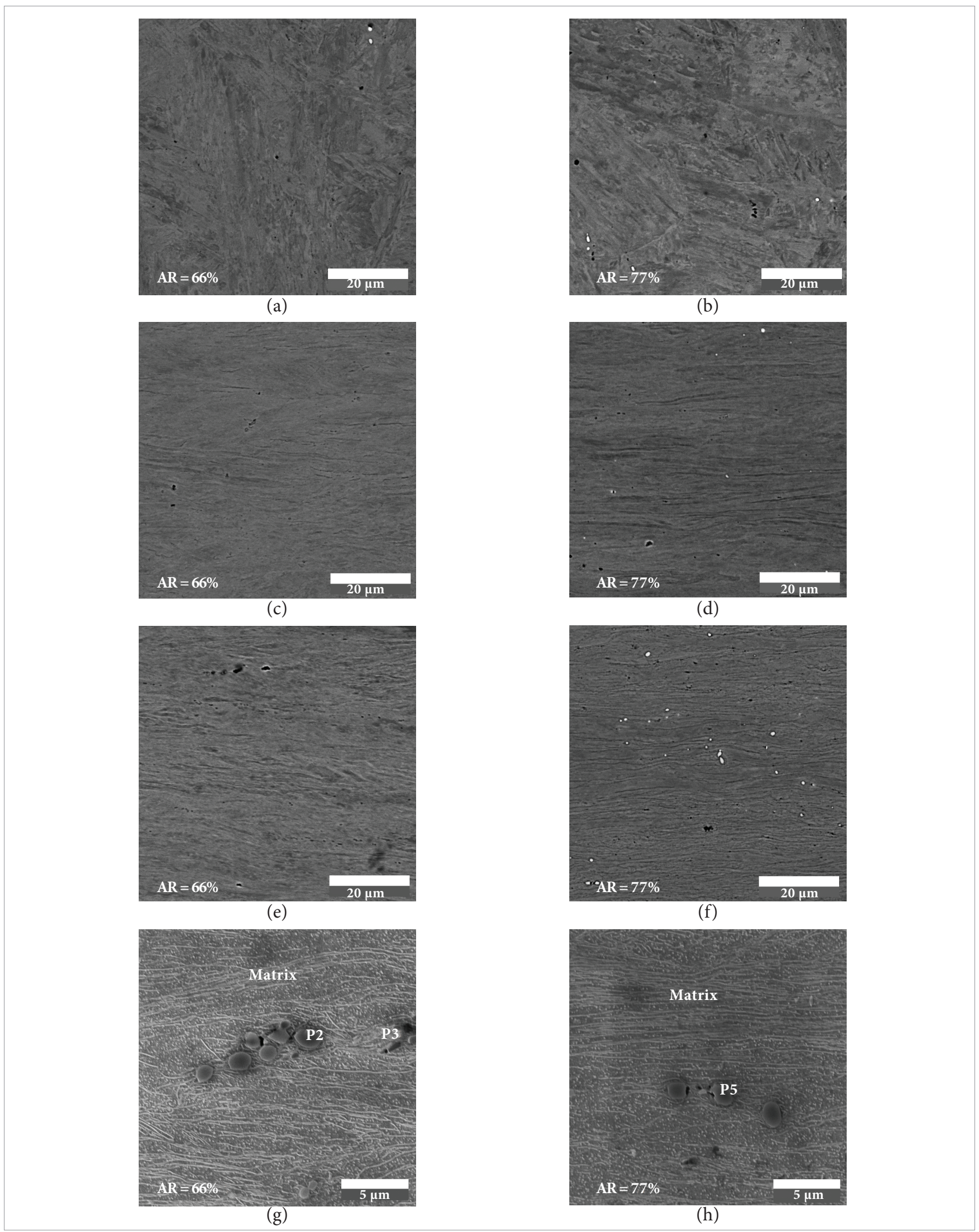

Figure 2. Microstructures of maraging steel under the conditions (a); (b) solution treated; (c); (d) deformed; (e); ( $f$ ) aging at $550^{\circ} \mathrm{C} / 1 \mathrm{~h}$ (SEM-BSE) and $(\mathrm{g}) ;(\mathrm{h})$ aging at $550^{\circ} \mathrm{C} / 16 \mathrm{~h}$ (SEM-SE). 
Figure 2 shows the microstructure of the maraging steel at different conditions. It is observed for solution treated sample (C-I and C-II) that the solution heat treatment at $1050^{\circ} \mathrm{C}$ for $1 \mathrm{~h}$ was effective in dissolving primary precipitates (formed during the early stages of maraging steel

After thermal aging at $550^{\circ} \mathrm{C}$ for 1 hour (Figs. 2e and $2 \mathrm{f}$ ), it can be seen that the microstructure is similar to deformed samples in $A R=66$ and $77 \%$ (Figs. $2 \mathrm{c}$ and $2 \mathrm{~d}$ ). This heat treatment time showed to be effective in relation to increased hardness (Fig. 1), due to presence of fine precipitates dispersed in the matrix, which contribute to the increase of this mechanical property (Hu and Wang, 2012). However, the technique of scanning electron microscopy, used in order to analyze the microstructure of this alloy, is not efficient to identify them in the matrix.

Increasing the annealing time to $16 \mathrm{~h}$ (Figures $2 \mathrm{~g}$ and $2 \mathrm{~h}$ ) promoted an increment in precipitation rate. These precipitates grew coarser in subsequent higher annealing times, but there still are fine precipitates elongated in the rolling direction, and few precipitates changed from elongate morphology to a spherical one. In this condition, it is observed some coalescence of precipitates having sizes of the order of $2 \mu \mathrm{m}$. Regardless of AR, the precipitates have similar morphologies. The EDS analysis (Table 2) showed that those precipitates, referred as $\mathrm{P} 2$ and P5, were depleted in Ni, and enriched in Mo and Ti (Figures $2 \mathrm{~g}$ and $2 \mathrm{~h}$ ).

In the analysis performed on the matrix - points 1 and 4 in Figs. $2 \mathrm{~g}$ and $2 \mathrm{~h}$, respectively -, compared to the nominal composition of the alloy, it can be said that the rolling processes or thermal treatments did not significantly alter the composition of the material in terms of $\mathrm{Mo}, \mathrm{Ti}, \mathrm{Cr}$ and $\mathrm{Ni}$ elements.

In relation to precipitates $\mathrm{P} 2$ and $\mathrm{P} 5$, a large increase of Mo and Ti was observed. This alloy contains low nickel, so it is not possible to stimulate the formation of $\mathrm{Ni}_{3} \mathrm{Mo}$ or $\mathrm{Ni}_{3} \mathrm{Ti}$ phases, which usually appear in the commercial maraging steels 250 and 350 (Padial et al., 2000). The presence of cobalt element in commercial alloys promotes the formation of $\mathrm{Ni}_{3} \mathrm{Mo}$. On the other hand, the maraging steel study in this work does not have Co (Co-free) and low Ni content. However, the alloy phase formed in this alloy can be $\mathrm{Fe}_{2}(\mathrm{Mo}, \mathrm{Ti}), \mathrm{FeMo}, \mathrm{FeTi}$ or $\mathrm{Fe}_{7} \mathrm{Mo}_{4}$ (Padial et al., 2000). The precipitate P3 features a larger enrichment of Ti in relation to $\mathrm{P} 2$ and $\mathrm{P} 5$, probably, the Ti-rich precipitates are carbides ( $\mathrm{TiC}$ ) or $\mathrm{Fe}_{2} \mathrm{Ti}, \mathrm{FeTi}$ (Castanheira et al., 2006). The $\mathrm{TiC}$ is formed by carbon, which is characterized as
Table 2. Chemical compositions of the constituent phases (wt.\%).

\begin{tabular}{|c|c|c|c|c|}
\hline Constituent & Mo & Ti & Ni & Cr \\
\hline Composition & 3.9 & 1.0 & 9.1 & 11.8 \\
\hline Matrix 1 & 4.6 & 1.2 & 9.2 & 12.1 \\
\hline Precipitate 2 (P2) & 16.0 & 3.0 & 4.7 & 14.1 \\
\hline Precipitate 3 (P3) & 7.6 & 12.5 & 6.4 & 9.9 \\
\hline Matrix 4 & 4.5 & 1.0 & 9.0 & 12.5 \\
\hline Precipitate 5 (P5) & 14.5 & 2.6 & 5.4 & 14.8 \\
\hline
\end{tabular}

an impurity of the material (Padial et al., 2000). Furthermore, other techniques are necessary, for example, an X-ray diffraction to determine the type of precipitate formed.

The SAE 4340 and 300M steels are considered hightensile steels, low-carbon and low-alloy steels, being used in the aerospace industry due to their excellent mechanical properties. Commercial maraging steels are being studied in order to replace the 4340 and $300 \mathrm{M}$ steels, especially in the aeronautical and aerospace industry. According to studies by Cardoso et al. (2013b), the SAE 4340 and 300M steels can achieve hardness values of $250 \mathrm{HV}$ and $350 \mathrm{HV}$, respectively, after drawing back. However, the maraging steel studied with forming processes and appropriate heat treatment can achieve hardness values around $670 \mathrm{HV}$, i.e., almost double the amount reported by the $300 \mathrm{M}$ steel.

\section{CONCLUSION}

Based on this investigation, the following conclusions can be drawn:

- The cold forming contributes to mechanical hardening, however an effective increase of hardness is obtained after thermal aging;

- The hardness increased significantly with low time thermal aging at $550^{\circ} \mathrm{C}$ due to precipitation of the second phase particles. The maximum value obtained was of $650 \mathrm{HV}$ at $550^{\circ} \mathrm{C} / 60 \mathrm{~min}$;

- Based on the average hardness values, the Co-free maraging steel is stable for up to 16 hours of aging at 
$550^{\circ} \mathrm{C}$. It is possible to note a subtle decrease in the hardness values for both $\mathrm{AR}$, due to coarsening of precipitates;

- Appropriate thermal aging promoted the precipitation of the second phase particles, rich in Mo and $\mathrm{Ti}$.

\section{ACKNOWLEDGEMENTS}

The authors are thankful to FAPESP, CNPq, CNPq Universal (476030/2011-0), DCTA/IEAv, Villares Metals SA and Multialloy-Metais e Ligas Especiais Ltda.

\section{REFERENCES}

Boakye-Yiadom, S., Khan, A.K. and Bassim, N., 2014, "A systematic study of grain refinement during impact of 4340 steel", Materials Science and Engineering: A, Vol. 605, pp. 270-285. doi: 10.1016/j.msea. 2014.03.066.

Callister, W.D.Jr., 2012, "Fundamentos da Ciência e Engenharia de Materiais: uma abordagem integrada", Rio de Janeiro: Editora LTC.

Cardoso, A.S.M., Abdalla, A.J., Lima, M.S.F., Bonjorni, F.M., Barbosa, M.J.R., Baptista, C.A.R.P. and Fanton, L., 2013a, "Study of Laser Welding and Heat Treatments Done in Different High Strength Steels: 4340, 300M, Maraging 300", SAE Technical Paper Series, Vol. 36, pp. 1-5. doi:10.4271/2013-36-0510.

Cardoso, A.S.M., Abdalla, A.J., Ueda, M., Lima, M.S.P. and Bonjorni, F.M., 2013b, "Microstructural Characterization of the 4340 and 300M Steels After Laser Welding, Heat Treatment and Surface Plasma", In: SAE, São Paulo.

Carvalho, L.G., Andrade, M.S., Plaut, R.L., Souza, F.M. and Padilha, A.F., 2013, "A dilatometric study of the phase transformations in 300 and 350 maraging steels during continuous heating rates", Materials Research, Vol. 16, No. 4, pp. 740-744. doi: 10.1590/S151614392013005000069.

Castanheira, M., Tikhomirov, V.V., Ozerskiy, A.D., Da Silva, J.E.R. and Lucki, G., 2006, "Influência dos Elementos de Liga e do Tratamento Térmico na Estrutura e Propriedades Mecânicas de um Aço Maraging sem Cobalto Resistente à Corrosão", Anais do $17^{\circ}$ CBECIMat, Brasil.

He, Y., Yang, K., Qu, W., Kong, F. and Su, G., 2002, "Strengthening and toughening of a 2800-MPa grade maraging steel". Materials Letters, Vol. 56, No. 5, pp. 763-769. doi: 10.1016/S0167577X(02)00610-9.

Hu, Z.F., Mo, D.F., Wang, C.X., He, G.Q. and Chen, S.C., 2008, "Different behavior in electron beam welding of 18Ni Co-free maraging steels". Journal of Materials Engineering and Performance, Vol. 17. No. 5, pp. 767-771. doi: 10.1007/s11665-007-9190-4.

Hu, Z.F. and Wang, C., 2012, "Effect of Tube Spinning With Subsequent Heat-Treatment on Performance and Microstructure Evolution of T250 Maraging Steel". Journal of Iron and Steel Research International, Vol. 19, No. 5, pp. 63-68. doi: 10.1016/S1006706X(12)60101-0.
Leitner, H., Schober, M., Schnitzer, R. and Zinner, S., 2011, "Strengthening behavior of Fe-Cr-Ni-Al-(Ti) maraging steels". Materials Science and Engineering: A, Vol. 528, No. 15, pp. 5264-5270. doi: 10.1016/j.msea.2011.03.058.

Lopes, J.C.O., 2007, "Os aços Maraging". Ciência e Tecnologia dos Materiais, Vol. 19, No 1-2, pp. 41-44.

Mahmudi, A., Nedjad, S.H. and Behnam, M.M.J., 2011, "Effects of cold rolling on the microstructure and mechanical properties of FeNi-Mn-Mo-Ti-Cr maraging steels". International Journal of Minerals, Metallurgy and Materials, Vol. 18, No 5, pp. 557-561. doi: 10.1007/ s12613-011-0477-y.

Mahmoudi, A., Ghavidel, M.R.Z., Nedjad, S.H., Heidarzadeh, A. and Ahmadabadi, M.N., 2011, "Aging behavior and mechanical properties of maraging steels in the presence of submicrocrystalline Laves phase particles". Materials Characterization, Vol. 62, No. 10, pp. 976-981. doi: 10.1016/j.matchar.2011.07.012.

Méndez, D., 2000, "Una revisión de los aceros Maraging", Revista Ciência Abierta, No. 28, Chile.

Nili-Ahmadabadi, M., 2008, "Improvement in mechanical properties of Fe-Ni-Mn maraging steel by heavy cold rolling". International Journal of Modern Physics B, Vol. 22, No 18-19, pp. 2814-2822. doi: 10.1142/SO217979208047638.

Padial, A.G.F., Monteiro, W.A., Andrade, A.H.P. and Rigo, O.D., 2000, "Microstrutural Analysis os 400 grade Maraging Steel After Thermomechanical Treatment". Thermec 2000, Estados Unidos.

Schnitzer, R., Schober, M., Zinner, S. and Leitner, H., 2010, "Effect of $\mathrm{Cu}$ on the evolution of precipitation in an Fe-Cr-Ni-Al-Ti maraging steel", Acta Materialia, Vol. 58, No. 10, pp. 3733-3741. doi: 10.1016/j. actamat.2010.03.010.

Sha, W., Chen, Z., Geriletu, X.X.X., Lee, J.S., Malinov, S. and Wilson, E.A., 2013, "Tensile and impact properties of low nickel maraging steel". Materials Science and Engineering: A, Vol. 587, pp. 301-303. doi: 10.1016/j.msea.2013.08.076.

Zang, G., Yang, X., He, X., Li, J. and Hu, H., 2013, "Enhancement of mechanical properties and failure mechanism of electron beam welded 300M ultrahigh strength steel joints". Materials and Design, Vol. 45, pp. 56-66. doi: 10.1016/j.matdes.2012.09.004. 